\title{
Transitional justice and the transition to democracy: looking at the past to gain a better perspective for the future
}

\author{
by Ulrich Karpen
}

$\mathrm{W}$ hen considering the best way for a country to deal with both its past and future during a period of transition after it has experienced major social and constitutional changes, three possible approaches can be taken:

- Looking back at the past, one may ask to what extent criminal justice can and must be applied. Certainly, trials in criminal courts after revolutions leading to deep-rooted changes to society and state have taken place are important tools to "do justice." Convictions have always been necessary and will always be. But is that enough? Certainly not!

- To cope with the future, one has to find constructive ways to find consolation, reconciliation and remorse.

- Finally, some conclusions need to be drawn on how the rule of law of a particular state provides the means of (and could be the basis for) finding a path through that area of unavoidable tensions - the transition from history to the future.

A revolution leading to the transformation of government, (constitutional) law, culture, economy, and society is part of the history of countries and always has been. Looking back at recent history, at least three turning points should be recalled.

These begin with Germany, which has twice undergone deep-rooted transformations. First came the collapse after the Second World War, when in 1945 the country was defeated and liberated at the same time. The Nürnberg Trials followed and the country had to make a completely new start. Then in 1989/90 the country was reunited, an unexpected "miracle of history." The Unification Treaty of 1990 dealt with many transition issues, as did various court decisions on the actions of the unjust government of the former German Democratic Republic and its supporters namely the "wall-killings" involving police officers and soldiers of the armed forces.

A second turning point was the transition of former socialist countries from 1989 onwards. It was a significant change of systems, from socialist democracy to free democracy, rule of law and social state.

Third, the world faced change in South Africa in the 1990s, and has recently witnessed revolutionary activity in Iraq, Afghanistan, Egypt, Tunisia, Libya, and Syria. We see the tribunals for former Yugoslavia and Ruanda at work, as well as the International Criminal Court and the tribunal for the former Pol Pot-regime in Cambodia. All of these countries took, and continue to take, a turn towards a more liberal human rights and rule-of-law democracy.

In other words, the problems of transitional justice can be studied as quite a topical subject these days, and the following remarks will deal with them in three parts: criminal justice, reconciliation, and rule of law understandings.

\section{TRANSITIONAL JUSTICE: APPLICATION OF CRIMINAL LAW}

\section{A German case study}

German court rulings in "wall killing" cases illustrate the shortcomings of criminal justice in such circumstances. On August 13, 1961, the government of the German Democratic Republic took security measures to seal the border between the Soviet and Western Allied Sectors of Berlin in order to cope with the increasing number of people escaping from East Berlin and the territory of the GDR to West Berlin and the Federal Republic of Germany. 
A wall, more than $35 \mathrm{~km}$ long, was build through the centre of Berlin, fortified with anti-personnel mines and automatic fire-systems. A total of 136 people were killed until the fall of the wall in 1989, primarily young men. After the unification of Germany criminal charges were brought against GDR border policemen and soldiers, as well as those who occupied positions of command and political power and were responsible for the border regime.

The accused claimed that their actions were legitimate: they had to obey orders of their supervisors in the police and military hierarchy. They also brought forward the argument that conviction would be a violation of the rule of law principle that there must be no ex post facto criminal law. The following sequence of events took place:

- Various lower courts convicted policemen and soldiers who had been involved in border killings.

- The Federal Court of Justice in 1993 confirmed the convictions on appeal.

- In 1996 the Federal Constitutional Court ruled that the convictions did not conflict with the "Basic Law" as Germany's Constitution is named.

- In addition, the European Court of Human Rights in Strasbourg in 2001 decided that the European Convention on Human Rights did not oppose the convictions.

- Later on some 35 cases were brought to German courts, and the accused were convicted, including members of the GDR National Defence Council, members of the Political Bureau of the Socialist Unity Party and, finally, the President of the Council of State of the former German Democratic Republic.

\section{The tension between positivism and natural law}

The basic problems with these cases lie in the conflict between positivism and natural law. On the one hand, deadly shooting at the border was - as the accused claimed - legal and thus justified under police law, special provisions to secure border control, and so on. On the other hand, these actions by the soldiers were, for example, criminal, and against all principles of just law, proportionality, and human rights. In short a grave breach of the law took place as we understand it to be "just" in our minds and hearts. The gap between positive law and natural law in these cases is so deep we conclude that "formal positive law" must give way to material justice.

Then there is the equally difficult problem of the prohibition of ex-post criminal law. It is a core provision of rule of law, and in the words of the Basic Law (para 103, s 2): "An Act may be punished only if it was defined by a law as a criminal offence before the Act was committed."

The problem was of course central to the Nürnberg Trials of 1945 and after. Members of the Nazi Regime and high-ranking military personnel were convicted on the basis of criminal provisions, which the allies enacted after the acts had been committed and sometimes even applied norms which did not exist earlier (war crimes, military aggression). In fact, the conviction of those who were responsible for the war killings prior to 1989 was based on (West) German criminal law. The question is indeed whether these convictions were a breach of the prohibition of ex post facto criminal law.

Looking more closely at the arguments which the relevant courts made to establish their decisions, Markus Rau has referred to the "natural law approach" of the Federal Court of Justice; the "teleological approach" of the Federal Constitutional Court; and the "Rule of Law approach" of the European Court of Human Rights Transitional Justice (see "The German Experience After 1989”, Lecture No 4 of the Rule of Law Programme South East Europe, Konrad-Adenauer-Stiftung, ed by Stefanie Ricarda Roos, Bucarest 2009, pp 10 et seq).

Each of these approaches is examined further below.

The "natural law approach" of the Federal Court of Justice

The Federal Court of Justice held:

"A ground of justification assumed at the time of the offence may (...) be disregarded due to a breach of higher ranking law if it expresses an obvious gross violation of basic principles of justice and humanity; the violation must be so grave that it infringes the legal opinions common to all peoples and being related to the value and dignity of man (...). The conflict between the positive law and justice must be so unbearable that the law as false law has to give way to justice. With these formulations (...) it was tried, after the end of the national socialist tyranny, to designate the most severe violations of law. The transfer of these considerations to the case at hand is not easy as the killings of people at the inner-German border cannot be equated to the national socialist mass murder. However, the comprehension reached then still holds true, i.e. that in the assessment of offences being committed on instruction of the state, one has to bear in mind whether the state has transgressed the outer limits set to him according to the common opinion in every country." (46 Neue Juristische Wochenschrift 141, at 144-45 (1993)).

The decision gives rise to some critical questions. The first is a basic one, as far as the methodology of jurisprudence is concerned: what are the "basic principles of justice of humanity"? What is, in other words, the "material" core of human rights, "material" justice? Is there a world-wide agreement on meaning and content? There seems to be - as with many broad terms and general clauses - a wide "semantic openness" (n 2, at p 13). Secondly, "according to the traditional view, national law that contravenes international law does not become invalid." This also holds true for the peremptory norms of international law (jus cogens). The idea of natural law being "interpreted" in the light of international human rights law undermines this traditional relationship between national and international law. 
The "teleological approach" of the Federal Constitutional Court

The court enriched the "natural law approach" by arguments of trust and confidence in the validity and binding force of law, namely of the prohibition of ex post facto criminal law, in a democratic state. The court held:

"The strict prohibition of ex post facto laws finds (...) its justification, in a state governed by the rule of law, in the particular foundation of confidence that backs criminal laws when they are adopted by a democratic legislator being bound to the basic rights. This particular foundation of confidence ceases to exist when the other state adopted criminal laws for the most severe criminal wrongs but excluded criminal liability in part through grounds of justification by way of calling upon (...) such criminal wrongs and abetting them, thus severely disregarding the human rights generally accepted in the international legal community. In doing so, the bearer of governmental authority set extreme state injustice which may hold its ground only so long as the governmental authority being responsible virtually exits.

"In this particular situation, the command of material justice which also implies acceptance of the international human rights forbids the application of such a ground of justification. The strict protection of confidence by Article 103, para. 2 of the Basic Law must step back then. Otherwise, the administration of criminal justice in the Federal Republic would conflict with its premises resulting from the principle of the state governed by the rule of law. The citizen who is subject now to the penal power of the Federal Republic is refused to invoke such a ground of justification ..." (50 Neue Juristische Wochenschrift 929, at 930-31 (1997)).

In assessing the arguments of the court, one must first note that the establishment of the ex post facto-prohibition is more subtle and rooted in the law's own rationality. (Rau, n 1, at 13). Josef Isensee argued that the GDR's criminal law must not be interpreted through the unhistorical glasses of the present in which the principle of the state governed by the rule of law applies (see Josef Isensee (ed), Vergangenheitsbewältigung durch Recht? Drei Abhandlungen zu einem deutschen Problem, 1992, 91, at 106).

It is - in Isensee's opinion - not the mere textual identity of an isolated criminal norm that corresponds to the prohibition of ex post criminal laws, but the content of the norm in the context of the whole state system, ie the real constitution of the policy. Bernhard Schlink stated:

"To regard as valid law not what is accepted and practiced as law but what should be accepted and practiced as law deprives the notion of law of one of its essential dimensions: reality." (see "Rechtsstaat und revolutionäre Gerechtigkeit" in Vergangenheit als Zumutung, Öffentliche Vorlesung, 20 April 1995, at 9 (1996)).

\section{The "rule of law approach" of the European Court of Human Rights}

The ECHR firstly referred to the provision of the GDR's "People's Police Act" and "State Borders Act" which authorised the use of firearms, including such norms as "when firearms are used, human life should be preserved where possible. Wounded persons must be given first aid." This was followed by: "The use of firearms is the most extreme measure entailing the use of force against the person" and "If possible firearms should not be used against juveniles".

The court held:

"These provisions, which therefore expressly included the principle of proportionality and the principle that human life must be preserved, should also be read in the light of the principles enshrined in the Constitution of the GDR itself. Article 89 \& 2 of the Constitution provided: 'Legal rules shall not contradict the Constitution'; Article $19 \$ 2$ provided: 'Respect for and protection of the dignity and liberty of the person are required of all State bodies, all forces in society and every citizen'; lastly, Article $30 \S \S 1$ and 2 provided: 'The person and liberty of every citizen of the German Democratic Republic are inviolable' and 'citizens' rights may be restricted only in so far as the law provides and when such restriction appears to be unavoidable'..."

Moreover, the first chapter of the Special Part of the GDR's Criminal Code provided: “The merciless punishment of crimes against ... peace, humanity and human rights ... is an indispensable prerequisite for stable peace in the world, for the restoration of faith in fundamental human rights (...) and the dignity and worth of human beings, and for the preservation of the rights of all' (...).” (European Court of Human Rights, Streletz, Kessler and Krenz $v$ Germany, judgment of March 22, 2001 (app nos 34044/96, 35532/97 and 44801/98, at $\$ \S 60$ 62, 64; see also European Court of Human Rights, $K-H W$ V Germany, judgment of March 22, 2001 (app no 37201797), at $\$ 54-57,59)$.

It may be misleading, however, to interpret the norms of an unjust, even criminal state from other provisions of its body of law as if that state were a rule of law state, whereas in fact it was authoritarian and systematically neglecting the essence of rule of law.

To sum up: all courts concurred in the final decision that the prohibition of ex post facto criminal law was not to be applied in these cases, and that finally the positive and formal law has to give way to material justice. This is "natural law interpretation" of the law and as such disputable and subject to all established critical arguments against it. 


\section{OTHER FORMS OF COPING WITH PAST \\ CRIMES AFTER TRANSITION: \\ "CONSTRUCTIVE JUSTICE"}

\section{Ways of looking back at the past to gain a better perspective of the future}

Criminal justice has a necessary part to play after periods of transition, but it cannot create a successful future on its own. Criminal justice looks back "in anger," and the system of trials, prosecution and conviction has its limits. This becomes obvious when the notion is thought through. If criminal justice is to be exercised in the fullest sense, a rather large part of the population should be brought before the court, eg after the Nazi and Communist totalitarian systems. This would contradict with the principle of a democratic rule of law state, so one must turn to other instruments to cope with the legacy of an unjust system.

\section{Truth and reconciliation procedures}

A well-known model for the process of reconciling a nation's past with its future is the establishment of a Truth and Reconciliation Commission (TRC), as in South Africa, Sierra Leone, Guatemala and Chile. As far as South Africa was concerned:

- in 1991 the apartheid regime of W de Klerck started negotiations with all political parties;

- in 1995 the Government of National Unity of President Nelson Mandela stepped into power;

- in 1996 this government established the TRC, then chaired by Archbishop Desmond Tutu.

The TRC was based on the establishing Act of 1995: “... a commission is necessary exercise to enable South Africans to come to terms with their past on a morally accepted basis and to advance the cause of reconciliation." (Promotion of National Unity and Reconciliation Act No 34 of 1995; cp Dullah Omar, former Minister of Justice).

South Africa wanted to realise a project of progressive politics, to strive for the ideal of a "constructive revolution”. The TRC's work was aimed at helping to establish reconciliation - the brotherhood of blacks and whites - and getting rid of apartheid while addressing the inequalities posed by rich and poor and offenders and victims.

Everyone was invited by the TRC to claim responsibility at the hearings, to tell, to explain, to testify, to put stone on stone for a building of truth. There was no general amnesty - which is also a possible instrument to structure a future after big changes, clashes and revolutions. The Commission, however, promised amnesty to accused individuals and granted it, with a few exceptions. Financial aid was also granted to victims.

The government's main arguments for establishing a TRC were:
- that tribunals encourage people to claim that they are not guilty, whereas the Commission invites them to tell the truth;

- tribunals punish, whereas the Commission rewards those who repent;

In its final report of 1998 the TRC:

- condemned torture, killings and other crimes, but made some prospective recommendations to empower the poor by contributions of business - a sort of wealth tax - to support social and economic justice, to strengthen educational justice, and to create equal opportunities;

- finally dealt with problems like AIDS and other barriers to a better future.

Nelson Mandela welcomed the final report, Thabo Mbeki (his successor as president) contested it before the courts. The people accepted it widely.

Of course some criticisms are sound. It must have been difficult for victims to understand and accept that those who committed crimes left the Commission room as free people. It is disputable whether amnesty - which is what this was - can erase the past.

\section{Access to information}

The TRC hearings produced a lot of detail, and this provided an incentive for legislation on access to information in various countries, notably Germany (InformationsfreiheitsG of September 5, 2005 (BGBl I, p 2722)) which particularly wanted to gain access to the files of the former GDR Ministry of Security (Stasi-UnterlagenG of December 20, 1991 (BGBl I, p 162)). Access to information fulfils the following purposes:

- supports the political, historical and legal recording of the past, which is part of the reconciliation process;

- protects individual rights of victims, eg in claiming damages;

- protects individuals against illegal use of their personal data.

Knowing the facts furthers consolation and reduces the "cognitive dissonance" between offenders and victims. Access to information uncovers knowledge and additional historical perspectives. Furthermore, it supports integration by making secret information public knowledge so that the truth is known instead of suspected. "Knowing" finally shows the faces on the bottom of the fountain. (Kader-Asmal, Zur Rolle der "Wahrheitskommission" in Südafrika, in: Gerd Hankel, Gerhard Stuby (ed), Strafgerichte gegen Menschheitsverbrechen, Zum Völkerstrafrecht 50 Jahre nach den Nürnberger Prozessen, Hamburg 1995, pp 465-80, at 473).

\section{Other instruments to deal with an unjust, even criminal past}

Usually civil servants and other administrative staff have been members of the old leading party or political elite, or 
at least close to it. It is impossible, however, to uphold an effective administration after transformation without their knowledge and experience. In Germany after the Second World War, the Allied forces established a bureaucratic procedure for "de-nazification" of public staff. After the reunification of Germany in 1990 civil servants retained their positions except:

- when they had violated the principles of humanity and rule of law, namely as vested in the Covenant of Civil and Political Rights and the UN Declaration of Human Rights;

- when they had been working for the Ministry of State Security and therefore further employment in the civil service could not be tolerated.

Using these criteria, evaluation of individuals took place. The same criteria were applied more or less to soldiers of the Peoples' Army. The German Parliament processed selfevaluation in the same way the ANC did in South Africa. Criticism and self-criticism requires the capability to repent and is of primary importance.

The results of a TRC or similar procedures enable people to undergo a process of re-education and look - as "teachers and students" - at historical events from a new and wider perspective. Finally, issues of property and expropriation had to be solved and a fair solution found. Paragraph 143, section 2 of the German Basic law, as amended after reunification, stated inter alia that illegal or illegitimate expropriations had to be reverted, except for expropriation during the occupation period (1945-49). This decision is still highly disputed today.

All in all one can observe that the foundations for a better future may be laid from constitutional and other public law perspectives, as well as from criminal and civil law.

\section{ROLE OF THE RULE OF LAW AND THE TRANSITIONAL PROCESS}

\section{System-criminality}

During the 20th century the world has learnt to distinguish better between individual crimes and systemcriminality, and individual responsibility before the Penal Code and state-criminality (macro-criminals like Hitler, Stalin, Pol Pot, Idi Amin, Saddam Hussein, Ruanda politicians and others). The development of "transitional criminal law" is a sign that legal practice is moving in the right direction. The International Tribunals for former Yugoslavia (Mladic, Karadzic, Srebrenica, Vukovar) at least do some justice to the victims and are a sign of hope to the world. The same is true for the International Criminal Court under the 1998 Statute of Rome, with its jurisdiction on genocide, crimes against humanity, war crimes and aggression.

This trend is also part of the development of international law which holds humanitarian interventions to be legitimate, such as those which took place in Kosovo or Libya. A number of questions are raised by such interventions - for example on the preservation of sovereignty and the renunciation of force - but these can be answered.

\section{Rule of law principles}

Transnational criminal law is part of a worldwide acceptance of rule of law principles which are not always implemented. There is agreement that:

"The 'rule of law' refers to a principle of governance in which all persons, institutions and entities, public and private, including the State itself, are accountable to laws that are publicly promulgated, equally enforced and independently adjudicated, and which are consistent with international human rights norms and standards. It requires, as well, measures to ensure adherence to the principles of supremacy of law, equality before the law, fairness in application of the law, separation of powers, participation in decision-making, legal certainty, avoidance of arbitrariness and procedural and legal transparency." (see, eg, Report of the Secretary General of the United Nations on the rule of law and transitional justice in conflict and post-conflict society; Doc. UN S/2004/616, no 6).

The rule of law is the lifeblood of any modern cosmopolitan society. It is the basis of sound economic development, and in the present era of globalization this is more significant than ever. There is agreement that human rights, separation of powers and access to an independent judiciary are essential elements of the rule of law:

"This is important because it raises the question of the normative foundation of the rule of law in international law: Whereas certain and most important general principles of the rule of law can be regarded as binding for all, there is, as far as there is no binding international law, wide room and discretion for national legislators to enact their individual body of national laws according to their own traditions and needs. We have to live with the permanent tension between international disciplines and commitments and national policy space." (Berlin, Federal Foreign Office, Experts Conference on the Rule of Law, November 30, 2007, conference documentation, $p$ 15).

Rule of law in this sense is not automatically secured in countries after a rule of law and democratic transition. It is an impulse for positive action, even though the European Commission evaluated two members of the EU in 2001 for making insufficient efforts to combat corruption, money laundering, and conflicts of interest in administration, as well as a failure to restructure police forces and the courts and get rid of "roped parties" who were not willing to change their minds and behaviour to adapt to new times.

It goes without saying that in any society the rule of law is never a matter of the "law in the constitution and in the books". Rule of law must be applied, implemented, supported and strengthened by the people. Effective rule 
of law requires educated acceptance and confidence in state institutions and persons holding office.

\section{RULE OF LAW AND TOLERANCE}

The central question is therefore what can the individual do to strengthen the rule of law and open democracy in the process of transition currently still in progress in some areas of the world and newly initiated in others. First, the careful study and teaching of rule of law principles, as well as practising them in governance, can lay the foundation for acceptance. Comparing government systems with those of other nations (which prove to be more effective and efficient) helps a lot. All this increases the chances of improving understanding of the pre-conditions, structures and importance of a rule of law democracy. Increased understanding is not per se a guarantee for the establishment of better morals and ethics in support of a free democratic order, but can certainly be a trigger to do so.

After studying, discussing and applying the rule of law with its elements of individual freedom, freedom of speech, and participation and responsibilities, one has established a firmly based position in support of a democratic rule of law system, its opportunities and challenges. But this is a frame of politics, not a strait-jacket. What is also necessary is the tolerance of people, opinions, designs and hopes for an individual and common future. People should enjoy integration within that frame, but also rejoice in a pluralism of opinions, perceptions and practical politics. Without this type of tolerance the movement for change will reach a dead end.

There is partnership as well as unavoidable tension between the firm basic principles and values of a free democracy, on the one hand, and a liberal tolerance to other systems on the other. After a period of transition, it might be difficult for people to keep this balance, but achieving it is essential in order to ensure a peaceful struggle for a better future.

Professor Dr Ulrich Karpen

Law Faculty, University of Hamburg 